\title{
Phytoremediation of Heavy metal Contaminated Wastes from Small-scale Gold Mining Using Pityrogramma calomelanos
}

\author{
Zar Che Win ${ }^{1, *}$, Leslie Joy L. Diaz ${ }^{2}$, Teresita R. Perez ${ }^{3}$, and Kiyohiko Nakasaki ${ }^{4}$ \\ ${ }^{1}$ Department of Industrial Chemistry, Dagon University, Yangon, Myanmar \\ ${ }^{2}$ Environmental Engineering Program, University of the Philippines Diliman, Quezon City, Philippines \\ ${ }^{3}$ Department of Environmental Science, Ateneo De Manila University, Quezon City, Philippines \\ ${ }^{4}$ School of Environment and Society, Tokyo Institute of Technology, Tokyo, Japan
}

\begin{abstract}
In this study, viability of employing the waste treatment technique for industrial application was conducted by setting up a phytoremediation protocol for field application where heavy metal (Arsenic and Copper) contaminated adsorbents, i.e. coco peat and nanofiber membrane, used for the treatment of wastewater were also included. An arsenic hyperaccumulator, Pityrogramma calomelanos was used for the treatment of mine wastes- tailings, coco peat and nanofiber membrane. Phytoremediation procedure was established by investigating planting parameters namely ; plot height - $(9 \mathrm{~cm}$ and 15 $\mathrm{cm}$ ) and planting distance- $(15 \mathrm{~cm}$ and $20 \mathrm{~cm})$ for a period of five months. Translocation factor and \% uptake of As and $\mathrm{Cu}$ by ferns were measured. According to the results, \% uptake of As and Cu by P. Calomelanos was $0.16 \%$ and $0.01 \%$ and translocation factor of As and $\mathrm{Cu}$ was 6.78 and 0.04 , respectively. Plant growth factors (root length, frond height and dry weight) in tailings mixture plant boxes and control soil were also determined. Accordingly, $P$. calomelanos grew well in tailings mixture without the symptom of phytotoxicity. Therefore, $P$. calomelanos can be used for the phytoremediation of the said heavy metal contaminated mine wastes. Based on this study, $15 \mathrm{~cm}$ plot height and $20 \mathrm{~cm}$ plant distance were suitable for field experiment although long term research data is required. The overall protocol for the treatment of mine wastes as field experiment was proposed based on the results.
\end{abstract}

\section{Introduction}

Mining for valuable metals, coal, and different wares shapes a significant piece of the economies of numerous nations [1]. The major environmental impact from waste transfer at mine site can be separated into two classes: the loss of productive land following its change to a waste stockpiling zone, and the presentation of silt, corrosiveness, and different contaminants into surrounding surface and groundwater from water running over uncovered dangerous or chemically reactive wastes [2]. The Philippines is considered as one of the profoundly mineralized nations per unit area of land. Mining activities are collected in Baguio Mining District, Benguet, Luzon where metallic reserves, for example, gold, silver, and copper are the biggest in the country [3]. Gold is the third most significant product in the Philippine export trade done by both small scale or large scale industry. Comparison of the mining technology of large-scale miners to small-scale miners, small- scale mining technologies leaves undeveloped and inefficient for the production and minimizing the environmental and health impacts because of lack of capital cost [4]. The small-scale gold processing place for this research released mining wastes (solid wastestailings and liquid waste-effluents). Mine tailings were stabilized in the tailings pond. Coco peat and polycaprolactone montmorillonite (PCL-MMT) nanofiber composite were utilized as adsorbents for the treatment of mining wastewater [5]. At a certain point, the spent adsorbent- coco peat and nanofiber membrane with heavy metals have to be properly disposed to minimize impacts on the surrounding environment. The estimated amount of mine tailing, coco-peat and nanofiber membrane produced per treatment are 3-4 tons, $25 \mathrm{~kg}$ and $20 \mathrm{~g}$ respectively.

Mining, producing, and the utilization of synthetic products (for example pesticides, paints, batteries, industrial waste, and land application of industrial or domestic sludge) can bring about heavy metal

* Corresponding author:zwin@upd.edu.ph 
contamination of urban and agricultural soils [6]. Heavy metals are the major environmental contaminants and represent a serious risk to human and animal health by their long term persistence in the environment. Among heavy metals related in the studied mine wastes, main concerns are arsenic (As) and copper $(\mathrm{Cu})$ because of their high concentration in the wastes and surpasses the standard [7].

$\mathrm{Cu}$ pollution for soil and groundwater mostly results from mine sites. At super optimal levels $(>100 \mathrm{mg} / \mathrm{kg}$ ), $\mathrm{Cu}$ is profoundly lethal to plants [8]. Most Cu-tolerant plants are excluders, and $\mathrm{Cu}$ accumulators have not been distinguished [9]. Copper is one of the poisonous heavy metals that have an ability to bind to albumen and other small molecules in the human body as 'free $\mathrm{Cu}^{\prime}$ to cause nerve damage. Excess copper consumption causes stomach upset, sickness, and diarrhea and can prompt tissue damage and disease [10].

Then again, As is exceptionally lethal and cancercausing, and hence the reclamation of As contaminated sites is imperative [10]. It exists normally in soil and rock, particularly in ores that contain $\mathrm{Cu}$ and $\mathrm{Pb}$. The most widely recognized inorganic types of As in nature are arsenate and arsenite [11]. Chronic exposure to As may cause changes in the skin, which is related to damage of blood vessels. Other acute effects include skin, liver, bladder, and lung cancer, sore throat, and nerve issue. Exposures to high concentrations of inorganic As can cause infertility and miscarriages in ladies, skin irritation, declining protection from infections, brain damage, and cardiovascular impacts, including hypertension, coronary vein disease, vascular disease, and atherosclerosis [12]. Studies show that fetal improvement is additionally influenced by chronic exposure to As [13].

Mine tailings can be burdened with critical amounts of heavy metals. Consequently, finding new and improving existing tailings treatment procedures is significant. Toxic metals are one of the primary contaminants present in mine tailings [14]. A few remediation techniques have been created to treat contaminated soil, mostly mechanically or physiochemically based remediation methods [15]. Phytoremediation is utilized over contaminated sites and have served to help and aid contamination cleanup efforts [16]. Phytoremediation of heavy metal polluted soil depends on the capacity of plants to accumulate metals at concentration substantially over those found in the soil in which they grow. This methodology has noteworthy economic advantages of over other techniques. Remediation of heavy metals by plant species can be partitioned into three groups: phytoextraction, metal accumulating plants are planted on polluted soil and later collected so as to expel metals from the soil; rhizofiltration, roots of metal accumulating plants retain metals from contaminated effluents and are later harvested to decrease the metals in the effluent; and phytostabilisation, metal-tolerant plants are utilized to lessen the versatility of metals, in this way, the metals are balanced out in the substrate [17].

This study focused on the problem of mine tailings and heavy metal loaded coco peat and nanofiber membrane generated in small-scale gold processing area with high $\mathrm{As}$ and $\mathrm{Cu}$ contents. Assessment of proper disposal of mine wastes such as mine tailings and evaluation of degradation of coco peat and the nanofiber mat after stabilization of the adsorbed heavy metal must be conducted. Therefore, after stabilization and precipitation process, phytoremediation was chosen as final treatment process [5]. The factors used for choosing plants for phytoremediation are: high metal tolerance, high bioaccumulation factor, short cycle of life, high propagation rate, wide distribution and large shoot biomass [18]. The native ferns species that can also grow naturally in mine sites is Pityrogramma calomelanos. This ferns is an arsenic hyperaccumulator [19-21]. $P$.

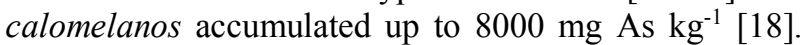
The highest level of As accumulation in P. calomelanos is $4034 \mathrm{mg} / \mathrm{kg}$ (in the fronds); $2256 \mathrm{mg} / \mathrm{kg}$ (in the roots) [22]. Although it is an As hyperaccumulator, the ferns still have ability to accumulate Cadmium (Cd), Lead $(\mathrm{Pb})$ and Zinc $(\mathrm{Zn})$. P. calomelanos can tolerate 4000 $\mathrm{mg} / \mathrm{kg} \mathrm{Pb}$ and $300 \mathrm{mg} / \mathrm{kg} \mathrm{Cd}$, respectively. To the best of knowledge, $P$. calomealnos is not a hyperaccumulator of $\mathrm{Cu}$. $P$. calomelanos could absorb $\mathrm{Cu}$ well especially in the belowground of the ferns [23-26]. Algo et al. (2014) observed that accumulation of total $\mathrm{Cu}$ concentration in P. calomelanos $(57.39 \mathrm{mg} / \mathrm{kg} \mathrm{Cu})$ and Pteris sp. (43.13 $\mathrm{mg} / \mathrm{kg} \mathrm{Cu}$ ) was found in two mining sites in Benguet, Philippines with $\mathrm{Cu}$ concentrations ranging from 71.1 to $384 \mathrm{mg} / \mathrm{kg}$ [27]. P. calomelanos could uptake 38.6 $\mathrm{mg} / \mathrm{kg}$ of $\mathrm{Cu}$ in fronds and $2393 \mathrm{mgkg}^{-1}$ in roots from the soil with $4302 \mathrm{mg} / \mathrm{kg}$ of $\mathrm{Cu}$ [23]. For this plant, systematic procedure to implement them in large scale remediation process has not been investigated.

In the present study, an attempt to set up a protocol for the phytoremediation of heavy metal contaminated mixture of mine tailings, coco peat and nanofiber membrane using ferns; $P$. calomelanos. There was a consideration for the setting up a protocol; planting parameters- plot height and plant distance. Planting parameters; height of plot (soil depth) and plant distance were decided based on the factors correlated with phytoremediation.

\section{Materials and Methods}

\subsection{Sample collection, plant selection and plant box preparation}

Mine tailings, contaminated coco peat and nanofiber membrane were collected from small-scale gold mine processing site in Kias, Benguet. Compost was purchased from the Material Recovery Facility in the University of the Philippines, Diliman, Quezon City, Philippines. Natural soil or garden soil that used as control was purchased from landscaping supplier. Pityrogramma calomelanos was chosen for this study.

The ferns with 4 or 5 fronds stage were collected from University of the Philippines campus and transplanted from the nursery bags to the plant boxes. Each plant box was constructed with aluminum frame lined with mosquito net and Tarpaulin sheet to prevent 
soil mixture from getting discharged with excess water. In the center, a hole was made by piercing the tarpaulin and plastic funnel was attached to collect the leachates. The containers were placed under plant boxes to collect any possible leachate from daily irrigation with water as well as biosafety of the site.

\subsection{Preliminary planting medium preparation and experimental design}

Plastic and other unwanted materials that can inhibit the growth of plants were removed form coco peat and compost. Mine tailings were crushed or homogenized to avoid clumping before mixing. Tailings, coco-peat and compost were mixed according to the ratio resulting from the biodegradation experiment which was the $60 \%$ tailings and $40 \%$ compost. Coco peat was mixed as $10 \%$ of the $60 \%$ tailings. After mixing, tailings mixture was transferred to the plant boxes of different plot height and plant distance of each fern. The amount of contaminated nanofiber membrane from wastewater treatment process of gold mining site is small and can be considered negligible. Natural soil or garden soil was used as control for each fern type.

For planting, two plant distances $(15 \mathrm{~cm}, 20 \mathrm{~cm})$ and two plot heights $(9 \mathrm{~cm}, 15 \mathrm{~cm})$ were assigned. Control plant boxes were also made with $25 \mathrm{~cm}$ plant distance and $20 \mathrm{~cm}$ plot height because plants can grow well in uncontaminated soil more than in contaminated soil. Twenty five ferns were grown in each plant box. Five samples were collected from each plant box at every monitoring schedule.

The Experimental set up is shown in Table 1.

Table 1. Plot set up

\begin{tabular}{|l|l|l|l|l|}
\hline \multicolumn{5}{|c|}{ P. calomelanos } \\
\hline Plant Box & Plant & Plant & Plant & Plant \\
I & Box II & Box III & Box IV & Box V \\
\hline $\mathrm{D}=15 \mathrm{~cm}$ & $\mathrm{D}=15 \mathrm{~cm}$ & $\mathrm{D}=20 \mathrm{~cm}$ & $\mathrm{D}=20 \mathrm{~cm}$ & Control \\
$\mathrm{H}=9 \mathrm{~cm}$ & $\mathrm{H}=15 \mathrm{~cm}$ & $\mathrm{H}=9 \mathrm{~cm}$ & $\mathrm{H}=15 \mathrm{~cm}$ & $\mathrm{D}=25 \mathrm{~cm}$ \\
& & & & $\mathrm{H}=20 \mathrm{~cm}$ \\
\hline
\end{tabular}

$\mathrm{D}=$ Distance between plants

$\mathrm{H}=$ Plot Height

Weekly checking and measuring of fern height was conducted to evaluate their growth in the tailings mixture. After harvesting, root length and dry weight of ferns were also measured every month.

\subsection{Sample collection and preparation for analysis}

Total duration of the growing time was five months. Every month, 5 ferns from each plant box were harvested randomly and separated into roots and fronds. Harvested material was thoroughly washed by using a three step-washing sequence consisting of two steps tap water, followed by distilled water. Samples were then air-dried, placed in an oven at $60{ }^{\circ} \mathrm{C}$ for $48-72 \mathrm{~h}$. Dried samples were weighed, mechanically ground $(<1 \mathrm{~mm})$ and stored in labeled plastic bags for further analysis.
Tailing mixture samples was collected every month. Sample taking pattern was shown in Figure 1. The tailing samples were taken from three points; left, right and middle around the area assigned on one fern that can be seen in Figure 1. Total samples for a fern was 9 samples. For the plant box with $9 \mathrm{~cm}$ plot height, tailing mixture was collected using hand driven stainless steel soil corer from three depths $(0-3 \mathrm{~cm}, 3-6 \mathrm{~cm}, 6-9$ $\mathrm{cm}$ ) of each box. For the plant box with $15 \mathrm{~cm}$ plot height, tailing mixture was also collected from three depths $(0-5 \mathrm{~cm}, 5-10 \mathrm{~cm}, 10-15 \mathrm{~cm})$. For the plots with $20 \mathrm{~cm}$ plot height, soil samples were collected from three depths $(0-6 \mathrm{~cm}, 6-12 \mathrm{~cm}, 12-20 \mathrm{~cm})$. After collection, 3 samples from same depth No. $(1,7,4),(2,5,8)$ and $(3,6,9)$ were made as a composite sample for analysis. Samples were air- dried, grounded with motor and pestle and sieved using $300 \mu \mathrm{m}$ (No.5 0) sieve to remove plant materials and other debris. It was then store in plastic bag for further analysis.

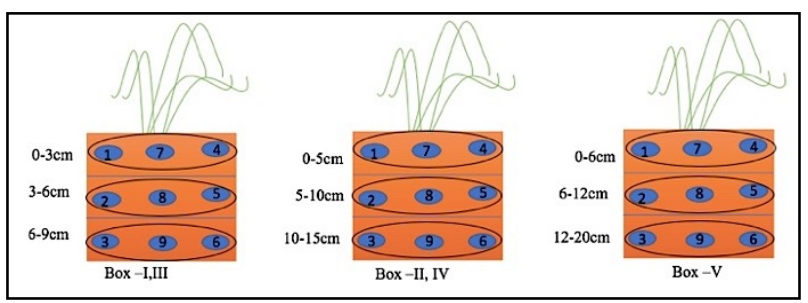

Fig. 1. Fern and soil samples harvesting pattern

\subsection{Total metal concentration in ferns and tailings mixture}

The total amount of $\mathrm{As}$ and $\mathrm{Cu}$ in the tailings mixture and control soil was determined using a method modified from ASTM D 5198-09. The metal concentrations were analyzed by Teledyne Leeman Labs Prodigy 7 Inductively Coupled Plasma Optical Emission Spectrometry (ICP-OES). After analysis, metal concentration from three depths was summed to get average value for the calculation of percent removal of $\mathrm{As}$ and $\mathrm{Cu}$ from tailings mixture. Total heavy metal contents of raw mine tailings, compost, coco peat and control soil were also determined using the same digestion method.

Dry ashing method was used for the digestion of fern samples [28]. The heavy metal concentrations were analyzed by Teledyne Leeman Labs Prodigy 7 Inductively Coupled Plasma Optical Emission Spectrometry (ICP-OES). \% Uptake of As and $\mathrm{Cu}$ by ferns were calculated through the heavy metal analysis data and plant growth data. The translocation process capacity of $\mathrm{As}$ and $\mathrm{Cu}$ from ferns shoots to roots is expressed by the translocation factor (TF).

\subsection{Overall protocol}

Ferns growth data such as root length, dry weight of ferns and fern height and uptake of heavy metals were suggested the idea of choosing planting parameters such as plot height and plant distance for phytoremediation. 
After proposing the fern species and planting parameters (plot height and plant distance), the overall protocol for the phytoremediation of mine wastes was set up.

\section{Results and Discussion}

\subsection{Effect of planting parameters on fern growth of $P$. calomelanos}

\subsubsection{Root length of ferns for $1^{\text {st }}$ and $5^{\text {th }}$ harvesting periods}

For the study of the effect of planting factor (plant distance and plot height), the behavior of root length in the $P$. calomelanos plant boxes with the plant distance; $15 \mathrm{~cm}$ and $20 \mathrm{~cm}$ and plot height; $9 \mathrm{~cm}$ and $15 \mathrm{~cm}$ respectively in the tailings mixture media were first checked. According to Figure 2, it could be clearly seen that root length of each box increased from $1^{\text {st }}$ period to $5^{\text {th }}$ period and seemed that no phytotoxicity occurred on the ferns. The progress of root length proved that the ferns grew well and absorbed increased heavy metals from tailings mixture.

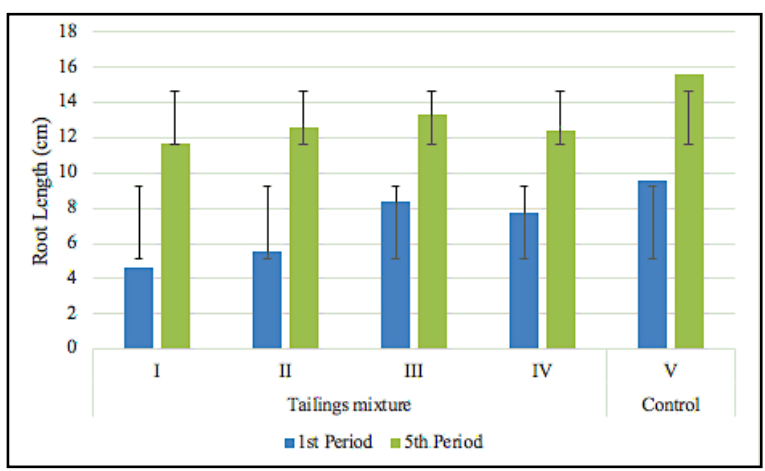

Fig. 2. Root length of ferns in tailings mixture and control plant boxes for $1^{\text {st }}$ and $5^{\text {th }}$ harvesting periods

The numerical values of root length from plant box I to IV for $P$. calomelanos were similar in $5^{\text {th }}$ harvesting period although their planting factors were different. The highest root length of $P$. calomelanos was found in plant box III with plot height $9 \mathrm{~cm}$ and plant distance of $20 \mathrm{~cm}$ for $1^{\text {st }}$ and $5^{\text {th }}$ harvesting periods.

Comparing the root length of tailings mixture plant boxes with control box as shown in Figure 2, among the 4 boxes, the box III with plant distance and plot height $(20 \mathrm{~cm}$ and $9 \mathrm{~cm}$ ) did not show much different with the control where the values are $(8.42 \mathrm{~cm}$ and $9.57 \mathrm{~cm})$ for $1^{\text {st }}$ period and $(13.30 \mathrm{~cm}$ and $15.64 \mathrm{~cm})$ for $5^{\text {th }}$ period respectively. Control box have longer root length than that of other tailings mixture boxes.

\subsubsection{Dry weight of ferns for $1^{\text {st }}$ and $5^{\text {th }}$ harvesting periods}

At the end of the each harvesting period, the dry weight (DW) of fronds and roots from tailings mixture plant boxes and from control was measured. The total DW of ferns from tailings mixture and control plant boxes are shown in Figure 3. There was a big difference of dry weight of ferns from every box for $1^{\text {st }}$ and $5^{\text {th }}$ periods. This showed a fast growth of ferns thru time. For $P$. calomelanos, dry matter in plant boxes I and II were lower than that of in plant boxes III and IV for $1^{\text {st }}$ harvesting period but almost all were the same for $5^{\text {th }}$ harvesting period except plant box I. Box I and II have same plant distance $(15 \mathrm{~cm})$, and Box III and IV have $(20 \mathrm{~cm})$ plant distance. According to previous comparison of dry matter weight for $1^{\text {st }}$ period, it seemed that plant distance had an effect on the dry matter. This is logical because during the first month, the ferns were still small and they have sufficient amount of space to grow compared with last period.

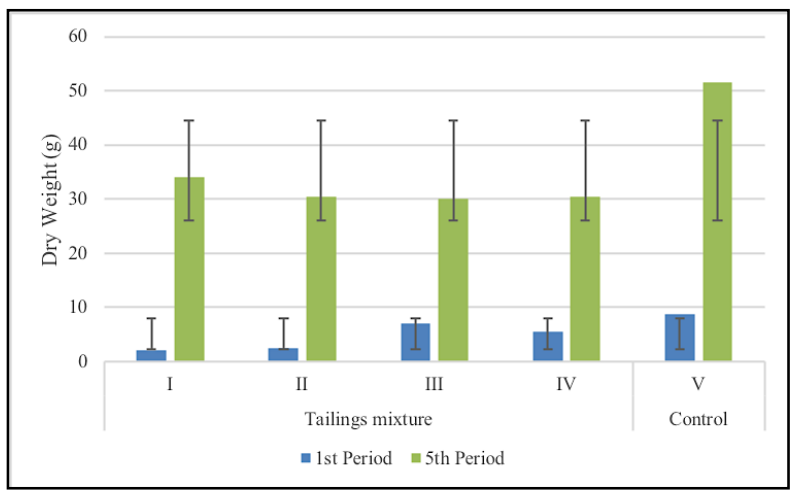

Fig. 3. Dry weight of ferns in tailings mixture and control plant boxes for $1^{\text {st }}$ and $5^{\text {th }}$ harvesting periods

Comparing the dry weight of $P$. calomelanos in tailings mixture plant boxes with control box, the dry weight of ferns in control plant box was higher than that of all tailings mixture plant boxes for both $1^{\text {st }}$ and $5^{\text {th }}$ periods. The planting parameters and the planting medium (physico-chemical properties) were different from control and other plant boxes.

\subsubsection{Frond height of ferns for $1^{\text {st }}$ and $5^{\text {th }}$ harvesting periods}

Height of fronds is one of the parameters that can assess the growth of a fern. From Figure 4, it could be observed that frond height of all of the ferns in every plant boxes were significantly increased from $1^{\text {st }}$ period to $5^{\text {th }}$ period. The growth patterns of $1^{\text {st }}$ period and $5^{\text {th }}$ period though, were not consistent.

For $P$. calomelanos, the highest frond height was noted in box IV $(15 \mathrm{~cm}$ plot height and $20 \mathrm{~cm}$ plant distance) in $1^{\text {st }}$ period while box II $(15 \mathrm{~cm}$ plot height and $15 \mathrm{~cm}$ plant distance) showed the highest frond height in $5^{\text {th }}$ period.

In comparison with the frond height of $P$. calomelanos tailings mixture plant boxes with control box, the height of fronds in control plant box was higher than that of all tailings mixture plant boxes for $1^{\text {st }}$ and $5^{\text {th }}$ periods. Compared with the plant box with highest frond height, the frond height of control was not significantly higher than that of tailings mixture plant box. 


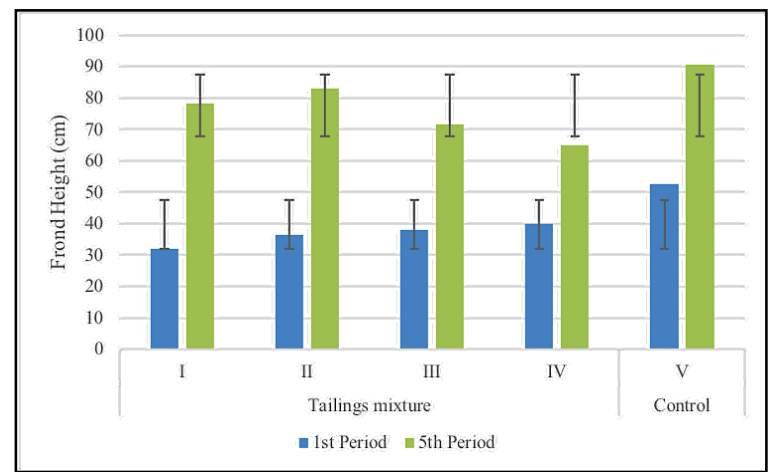

Fig.4. Frond height of ferns in tailings mixture and control plant boxes for $1^{\text {st }}$ and $5^{\text {th }}$ harvesting periods

In general, plant growth factors- root length, dry weight and frond height of control were higher than that of ferns grown in tailings mixture plant boxes. The planting factors of control were different from tailings mixture plant boxes. Control boxes has higher plot height $(20 \mathrm{~cm})$ and plant distance $(25 \mathrm{~cm})$. It was expected though that better and higher fern growth can be observed in control soil. The difference of plant growth can be assumed that the tailings mixture has significant amount of heavy metal but control just had a background concentration of the metal in the soil. The ferns in the control boxes suffered less metal stress compared to the ferns grown in contaminated tailings mixture. The control soil was garden soil that had enough nutrients to support plant growth.

One of the considerations about metal stress of ferns during experiment is known that natural soils contained enough plant nutrients and microorganisms compared with the mine tailings. Compost though contained a variety of microorganism and plant nutrients compared to garden soil. It was known that microorganism in the soil and rhizosphere help in the growth of ferns and uptake of heavy metal $[29,30]$. Theoretically, the ferns grown in tailings mixture must have shown higher growth than that of ferns grown in control soil. According to Figures 2-4, the ferns growth factors- root length, dry weight and frond height of $P$. calomelanos grown in tailings mixture were lower than that of control ferns grown in natural soil although tailings mixture was made of $40 \%$ compost. Also in the statistical analysis, planting factors have no significant effect on the growth of ferns. The metal stress on the ferns in the tailings mixture was due to the higher amount of As and $\mathrm{Cu}$ than compared to the control soil.

Experimental site observations showed that the fern species established successfully in the plant boxes and grew without showing phytotoxicity symptoms.

\subsection{Heavy metal concentration of raw phytoremediation media}

The tailings mixture used in phytoremediation was prepared by mixing of tailings, compost and coco peat where the amount of $\mathrm{As}$ and $\mathrm{Cu}$ in the raw tailings mixture before phytoremediation were $168.85 \mathrm{mg} / \mathrm{kg}$ and $5201.85 \mathrm{mg} / \mathrm{kg}$. The compost and natural soil had a small amount of As and $\mathrm{Cu}$ compared to mine tailings and spent coco peat but $\mathrm{Cu}$ amount which were over the maximum permissible limits of soil according to WHO [31]. The physico-chemical characteristics of mine tailings, compost and coco peat were also presented in Table 3.

Table 2. Heavy metal concentration of mine tailings, coco peat, compost and natural soil

\begin{tabular}{|l|c|c|}
\hline \multirow{2}{*}{ Samples } & \multicolumn{2}{c|}{$\begin{array}{c}\text { Heavy metals concentration } \\
\text { (mg/kg of sample) }\end{array}$} \\
\cline { 2 - 3 } & $\mathrm{As}$ & $\mathrm{Cu}$ \\
\hline Mine Tailings & 156.63 & 4641.85 \\
\hline Coco peat & 9.74 & 340.9 \\
\hline Compost & 2.48 & 219.6 \\
\hline Natural soil & 4.54 & 104.1 \\
\hline $\begin{array}{l}\text { *Maximum } \\
\text { allowable limit }\end{array}$ & 20 & 100 \\
\hline $\begin{array}{l}* * \text { Phytotoxicity } \\
\text { level }\end{array}$ & 10 & 100 \\
\hline
\end{tabular}

*World Health Organization (WHO), Food and Agricultural Organization (FAO), **[32]

Table 3. Physico-chemical characteristics of mine tailings, compost and coco peat

\begin{tabular}{|l|c|c|c|}
\hline \multicolumn{1}{|c|}{ Characteristics } & $\begin{array}{c}\text { Mining } \\
\text { tailings }\end{array}$ & Compost & $\begin{array}{c}\text { Coco } \\
\text { peat }\end{array}$ \\
\hline $\mathrm{pH}$ & 7.6 & 6.18 & 6.54 \\
\hline $\begin{array}{l}\text { Nitrogen(N), Total, } \\
\%\end{array}$ & $<$ LLD & 0.559 & - \\
\hline $\begin{array}{l}\left.\text { Phosphorous ( } \mathrm{P}_{2} \mathrm{O}_{5}\right), \\
\text { Total, \% }\end{array}$ & 0.098 & 0.508 & - \\
\hline $\begin{array}{l}\text { Organic Matter(OM), } \\
\text { Total, \% w/w }\end{array}$ & 1.106 & 28.613 & 94.92 \\
\hline $\begin{array}{l}\text { Lignin content,\% } \\
\text { w/w dry basis }\end{array}$ & - & - & 49.86 \\
\hline $\begin{array}{l}\text { Total cellulose,\% } \\
\text { w/w dry basis }\end{array}$ & - & - & 62.81 \\
\hline
\end{tabular}

\subsection{Percent uptake of heavy metal by ferns in tailings mixture and control plant boxes}

Heavy metal content of tailings mixture occupied by a ferns according to their root length was also calculated from the value of raw tailings mixture. Calculation was based on the fact that roots of a single fern occupied equal soil volume. In each box, every single fern roots would occupy equal soil volume because the ferns were planted on a grid.

Percent uptake of a fern was calculated as follows : $\%$ uptake of a fern $=$ Total As concentration in ferns/Total As concentration in soil $\times 100$

The $\%$ uptake of ferns in control plant boxes are presented in Figures 5 and 6. Although the amount of heavy metal in control was very low compared to tailings mixture, the ferns showed uptake of $\mathrm{As}$ and $\mathrm{Cu}$. Percent uptake of As of ferns increased form $1^{\text {st }}$ period to $5^{\text {th }}$ period but the $\%$ uptake of $\mathrm{Cu}$ was decreased from $1^{\text {st }}$ to $5^{\text {th }}$ period. 
$P$. calomelanos can uptake $\mathrm{As}$ and $\mathrm{Cu}$ from the soil. The control soil had just a background level of heavy metals so that data on uptake was not consistent although all the plants were grown under identical environmental conditions. The various physical and chemical properties of the control soil may have an effect on heavy metal uptake but this is not the focus of this study.

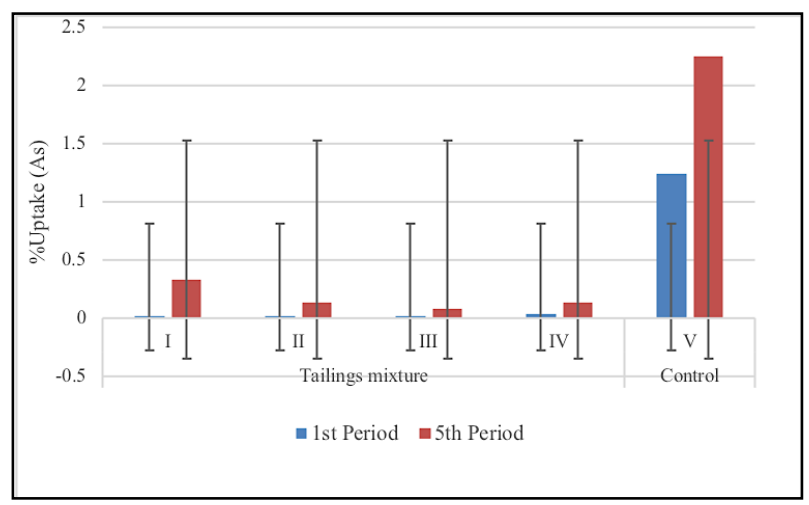

Fig. 5. Percent uptake of As by ferns for $1^{\text {st }}$ and $5^{\text {th }}$ harvesting periods

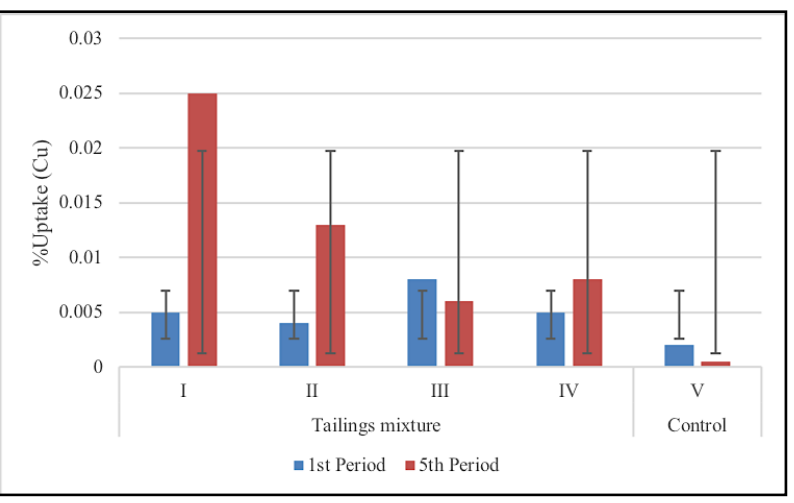

Fig. 6. Percent uptake of $\mathrm{Cu}$ by ferns for $1^{\text {st }}$ and $5^{\text {th }}$ harvesting periods

The percent uptake of heavy metal (As and $\mathrm{Cu}$ ) by ferns in tailings mixture for $1^{\text {st }}$ and $5^{\text {th }}$ periods are presented in Figures 5 and 6. The fern As uptake is related to the As concentration of fern and dry biomass [19]. As shown, \% uptake of As by ferns was significantly increased from $1^{\text {st }}$ period to $5^{\text {th }}$ period. When the \% uptake of As in tailings mixture plant boxes was studied, all plant boxes (I, II, III, IV) showed the nearly same uptake values for $1^{\text {st }}$ period but for $5^{\text {th }}$ period, the uptake of plant box I with $9 \mathrm{~cm}$ plot height and $15 \mathrm{~cm}$ plant distance was higher than other three boxes. $P$. calomelanos was proven by many researcher as As hyperaccumulators during phytoextraction $[19,21,39]$. Phytoextraction efficiency is not only indicated by the degree of hyperaccumulation, but also by the biomass produced [25]. Also, differences in the amount of As extracted from the soil by the plant are likely related to: i) As availability in the soil, ii) growth period of plant, and iii) whether or not the plants grew under greenhouse or field conditions [38]. As shown, percent uptake of $\mathrm{Cu}$ by ferns was significantly increased from $1^{\text {st }}$ period to $5^{\text {th }}$ period except plant box III although the values of $\%$ uptake of $\mathrm{Cu}$ were differed from one plant box to another with different plot heights and plant distances. When the \% uptake of $\mathrm{Cu}$ in tailings mixture plant boxes was studied, all plant boxes I, II, IV showed the nearly same uptake values for $1^{\text {st }}$ period except plant box III with $9 \mathrm{~cm}$ plot height and $20 \mathrm{~cm}$ plant distance but for $5^{\text {th }}$ period, the uptake of plant box I with $9 \mathrm{~cm}$ plot height and $15 \mathrm{~cm}$ plant distance was higher than other three boxes.

$P$. vittata, $P$. calomelaonos and other ferns species were collected from the tailings pond and tunnel in Benguet and analyzed for the $\mathrm{Cu}$ content in the study of [27]. The result was that the highest total $\mathrm{Cu}$ concentration accumulated in $P$. calomelanos (57.39 $\mathrm{mg} / \mathrm{kg} \mathrm{Cu})$ and Pteris sp. $(43.13 \mathrm{mg} / \mathrm{kg} \mathrm{Cu})$ that amount was uptaken from the soil with $\mathrm{Cu}$ concentration of ranging from 71.1 to $384 \mathrm{mg} / \mathrm{k}$ [27]. The concentration of $\mathrm{Cu}$ in soil for that study and the tailings mixture in this study was different. The tailings mixture has $\mathrm{Cu}$ concentration of $5201.85 \mathrm{mg} / \mathrm{kg}$ of dry weight. According to uptake of ferns, $P$. calomelanos can uptake highest amount of $\mathrm{Cu} 92.24 \mathrm{mg} / \mathrm{kg}$ when the soil metal content was $5201.85 \mathrm{mg} / \mathrm{kg}$. The excess $\mathrm{Cu}$ in plants leads to oxidative stress inducing changes in the activity and content of some components of the antioxidative pathways [42]. Also, the bioavailability of heavy metals like $\mathrm{Cu}$ is based on the influence of soil physical factors [10]. Generally, it could be assumed that if the plot height is longer, the root can grow longer and absorb more metals.

Plant distance was assumed to correlate with dry biomass and plot height as well as root length. When the root length was longer, the calculated heavy metal contents of soil was higher. At the same time, the concentration of heavy metals of the ferns could also be greater when the dry weight of biomass was higher. Therefore, the $\%$ uptake of $\mathrm{Cu}$ was higher from $1^{\text {st }}$ period to $5^{\text {th }}$ period except plant box III and VI because the root length and dry weight also increased thru time.

\subsection{Translocation factor}

Some heavy metal accumulator plants tend to store heavy metals in its roots, while others translocate these in its shoot and/or leaves. The efficiency of phytoremediation can be quantified by calculating translocation factor. The translocation factor $(\mathrm{TF})$ is commonly used to evaluate the heavy metals storage in plant tissues, where $\mathrm{TF}>1$ indicates the effective translocation of heavy metals from roots to shoots[33, 34]. Translocation factor (TF) of $\mathrm{As}$ and $\mathrm{Cu}$ for $P$. calomelanos in control soil and tailings mixture for $1^{\text {st }}$ and $5^{\text {th }}$ harvesting period can be seen in Figure 7 and 8 . As shown, TF values of As for control plant boxes were greater than one in $1^{\text {st }}$ period and $5^{\text {th }}$ period. This means that the amount of heavy metals in the frond was higher than the amount in roots and the metals can translocate from root to shoot. For $\mathrm{Cu}$, TF value of control plant box for $1^{\text {st }}$ period was greater than one, it means that $\mathrm{Cu}$ in the ferns grown in natural soil can translocate from roots 
to fronds, this results was in contrast with Algo et al. (2014) and Dahilan and Dalagan (2017). But for $5^{\text {th }}$ period, it could not be calculated because no $\mathrm{Cu}$ accumulation in frond accoridng to the analysis results. Therefore, the result of $P$. calomelanos in $1^{\text {st }}$ period might be experimental error. The amount of $\mathrm{Cu}$ in the soil is low and may not be consistent [36].

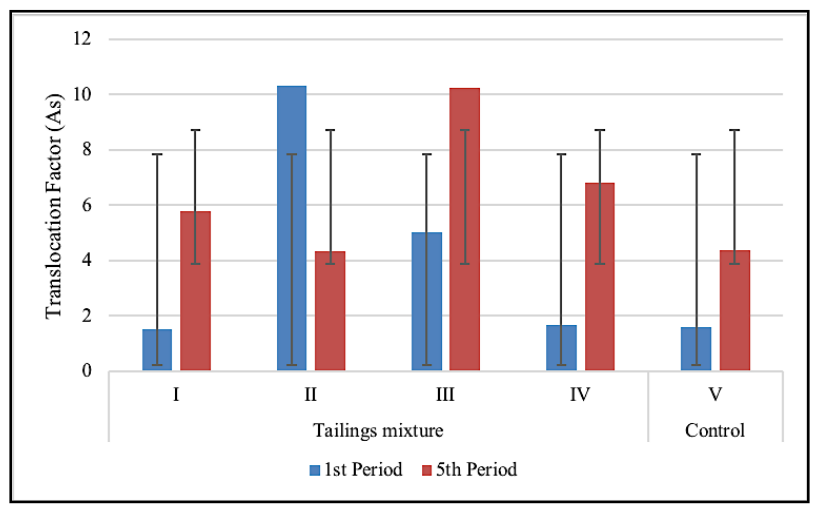

Fig. 7. Translocation factor of ferns for $1^{\text {st }}$ and $5^{\text {th }}$ harvesting periods (As)

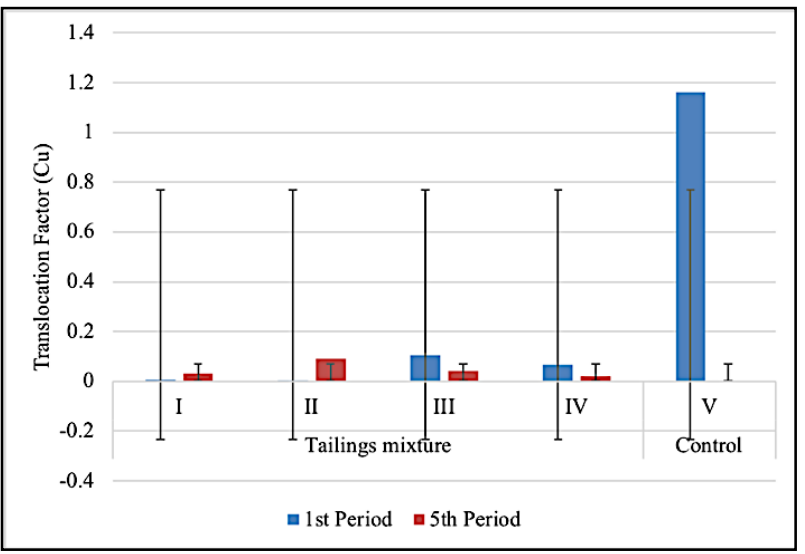

Fig. 8. Translocation factor of ferns for $1^{\text {st }}$ and $5^{\text {th }}$ harvesting periods $(\mathrm{Cu})$

For Arsenic, $\mathrm{TF}$ of ferns are greater than $1 . \mathrm{TF}>1$ represent that translocation of metals effectively was made to the shoot from root $[19,34,37]$. A key feature of metal accumulation is the efficient metal transport from roots to shoots, characterized by the translocation factor being greater than one [16,38]. This results are in agreement with many studies where TF of Arsenic of $P$. calomelanos was greater than $1[21,25,39,40]$. Theoretically, TF value must be larger from period to period because according to plant growth data, all ferns grew well from $1^{\text {st }}$ to $5^{\text {th }}$ period. In this case, TF value of $P$. calomelanos was correlated with the growth data except for plant box II where the TF value was higher in $1^{\text {st }}$ period than that of $5^{\text {th }}$ period. According to ferns As data, As contents of frond and root increased thru time. There might be one consideration that although most of the metal translocate to upper part of ferns, some may be volatile because of the action of microorganism [12,41].

For $\mathrm{Cu}, \mathrm{TF}$ value of the ferns were lower than one. It means that most of the $\mathrm{Cu}$ uptake were stored in below ground part and not translocated to upper ground part. In general, those results stood in agreement with many studies which found that the accumulation of $\mathrm{Cu}$ was greater in roots in comparison with shoots of $P$. calomelanos [17, 27]. Algo et al. (2014) stated that TF of $\mathrm{Cu}$ of $P$. calomelanos was lower than 1 and most of $\mathrm{Cu}$ was accumulated in the roots. Furthermore, other $\mathrm{Cu}$ non-hyperaccumulator plants could not translocate and stored more metal in the roots. Almost all of TF of ferns were lower in $5^{\text {th }}$ period than that of $1^{\text {st }}$ period except plant box I and II although the fern growth data was increased from $1^{\text {st }}$ period to $5^{\text {th }}$ period.

Plants also require certain heavy metals for their growth and development, and excessive amounts of these metals can become toxic to plants [30]. Higher metal concentrations in soil likely inhibit the growth and development of plants and may thus reduce the efficiency of phytoremediation [30]. Although there was no sign of phytotoxicity in this species of ferns, it might not be able to accumulate $\mathrm{Cu}$ very well because of high metal content in the tailings mixture. However, the plant nutrients and microorganism from compost can support the growth of plant and uptake of ferns to some extent. For that reason, some $\mathrm{Cu}$ could be translocated from below ground to above ground part of ferns.

\subsection{Setting up a phytoremediation protocol}

The objective of this study was to set up a phytoremediation protocol to treat mine tailings and heavy metal contaminated coco peat and nanofiber membrane from small scale mining industry. To implement this, the results from phytoremediation experiments, in term of $\%$ uptake of $\mathrm{As}$ and $\mathrm{Cu}$ by ferns and \% removal $\mathrm{As}$ and $\mathrm{Cu}$ from tailings mixture were utilized.

Table 4 shows the concentration and $\%$ removal of heavy metals (As and $\mathrm{Cu}$ ) after 5 months phytoremediation where the average concentration of As in $P$. calomealnos plant boxes was $31.81 \mathrm{mg} / \mathrm{kg}$. The average $\mathrm{Cu}$ concentration was $636.32 \mathrm{mg} / \mathrm{kg}$. The \% uptake of $\mathrm{As}$ and $\mathrm{Cu}$ by $P$. calomelanos was 0.16 and 0.013 respectively while the \% removal of $\mathrm{As}$ and $\mathrm{Cu}$ in plant boxes were 81.16 and 87.76 respectively. There seemed to be mismatch in the amount of heavy metal removed from the tailings mixture $(\sim 80 \%)$ and the amount of heavy metal taken up by the ferns $(<1 \%)$. The material balance of heavy metal in the tailings mixture and in the fern could not be obtained. The assumption for the higher removal of heavy metal aside from the $\%$ uptake was that the excess removal of metal must have gone into the leachate or may have accumulated in the microbial consortia and some may have volatilized, such as As which have been converted to Arsine gas by the action of certain microorganisms. The soil is in complex entity in consideration of its properties including the microbial consortia and heavy metal present. Although the material balance was not available, approximately $\sim 80 \%$ removal of heavy metals was obtained in plant boxes. 
Table 4. Concentration and \% removal of heavy metal (As, $\mathrm{Cu})$ in $5^{\text {th }}$ harvesting period

\begin{tabular}{|c|c|c|c|c|c|}
\hline \multirow{2}{*}{$\begin{array}{c}\text { Plant } \\
\text { box } \\
\text { no. }\end{array}$} & Plot height, & \multicolumn{2}{|c|}{ As } & \multicolumn{2}{c|}{$\mathrm{Cu}$} \\
\cline { 3 - 6 } & & $\mathrm{mg} / \mathrm{kg}$ & $\begin{array}{c}\% \\
\text { removal distance }\end{array}$ & $\mathrm{mg} / \mathrm{kg}$ & $\begin{array}{c}\% \\
\text { removal }\end{array}$ \\
\hline I & $9 \mathrm{~cm}, 15 \mathrm{~cm}$ & 30.81 & 81.76 & 824.4 & 84.15 \\
\hline II & $15 \mathrm{~cm}, 15 \mathrm{~cm}$ & 35.63 & 78.90 & 763.2 & 85.33 \\
\hline III & $9 \mathrm{~cm}, 20 \mathrm{~cm}$ & 34.02 & 79.85 & 508.9 & 90.22 \\
\hline IV & $15 \mathrm{~cm}, 20 \mathrm{~cm}$ & 26.80 & 84.13 & 448.8 & 91.37 \\
\hline
\end{tabular}

According to heavy metal $(\mathrm{As}, \mathrm{Cu})$ uptake data, $P$. calomelanos could uptake more $\mathrm{As}$ and $\mathrm{Cu}$ in plant boxes with plot height $9 \mathrm{~cm}$ and plant distance $15 \mathrm{~cm}$ but plant boxes with $15 \mathrm{~cm}$ plot height and $20 \mathrm{~cm}$ plant distance was more suitable for phytoremediation of As and $\mathrm{Cu}$. This assumption though was only for 5 months experiment. A study stated that after 10 months, the roots of $P$. calomelanos reached up to $60 \mathrm{~cm}$ [39]. However, the highest soil As reduction was found only in $0-20 \mathrm{~cm}$ and $0-15 \mathrm{~cm}$ soil in 27 months and 24 months studies [39].

Phytoextraction is a root-based biotechnology, and the depth of remediation is limited by the root distribution of the cultivated plant [42]. To enhance phytoextraction of metals from contaminated soils, plant roots should grow as widely as possible to absorb more heavy metals [43]. Contamination of heavy metals was mainly concentrated in the top $20 \mathrm{~cm}$ at the site [17]. In addition, the nature of the root system of $P$. calomelanos should be considered. P. calomelanos possesses strong creeping rhizome system [44]. Plants need to grow widely to absorb more heavy metal. Based on studies, the plant distance and plot height could be adjusted and set according to intended clean up time of heavy metals. Generally, it could be proposed that plot height $15 \mathrm{~cm}$ and plant distance $20 \mathrm{~cm}$ are suitable for the phytoremediation of $\mathrm{As}$ and $\mathrm{Cu}$ contaminated tailings mixture with the aid of $P$. calomelanos. Therefore, tailings, coco peat and nanofiber membrane retrieved from the sedimentation tank, filter bed and adsorption column can be treated near the processing site according to the procedures presented in Figure 9.

The first step is the selection of site for phytoremediation. A shallow excavation on the ground can be made with the intended grids, lined with an impermeable polymer sheet to prevent contamination of ground and an appropriate leachate collection system. While the site is being prepared, tailing materials (tailings, coco peat and nanofiber membrane) are characterized and mixed with compost based on the ratio of phytoremediation experiment (54\% mine tailings, $6 \%$ coco peat and $40 \%$ compost). P. vittata is chosen as metal accumulator because it can uptake more As and $\mathrm{Cu}$ than $P$. calomelanos in the phytoremediation experiment. The plot height is $15 \mathrm{~cm}$ and distance between ferns is $20 \mathrm{~cm}$. The experiment time may be set at 5 months. During the acclimatization period of the fern, they are watered two times a day for two weeks, after which once a day will suffice until the end of experiment. Weekly weeding is also required for monitoring the ferns.

After 5 months, the heavy metal content of tailings mixture is analyzed. If the concentration of heavy metals in the mixture does not meet the regulatory limit, for example $20 \mathrm{mg} / \mathrm{kg}$ of As and $100 \mathrm{mg} / \mathrm{kg}$ of $\mathrm{Cu}$ according to WHO, growing of ferns will be continued. When the concentration of heavy metals is within maximum allowable limit, the ferns can be harvested and disposed using suitable disposal method such as precipitation of metal via hydrothermal extraction. The tailings mixture is removed from the site and can be used as soil conditioner, agricultural soil or any other purposes. The leachate collected from the leachate collection system has to be managed following the water quality guideline of Department of Environment and Natural Resources (DENR) Philippines.

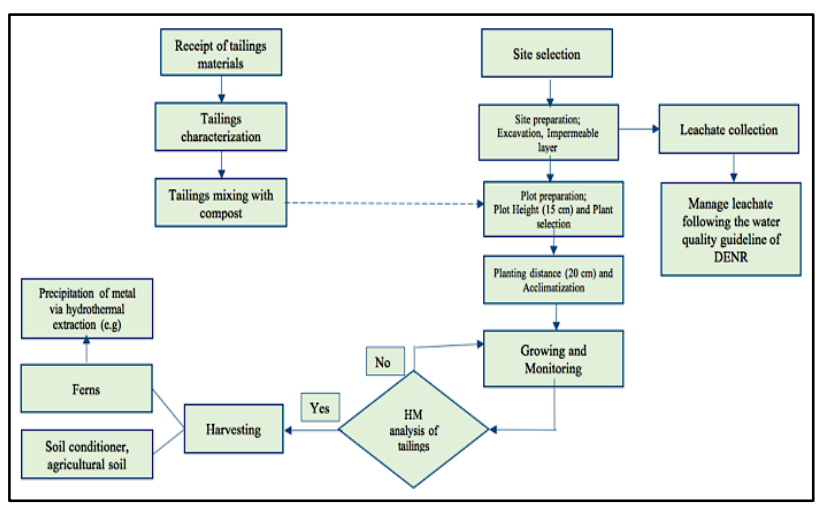

Fig. 9. Overall procedure of phytoremediation

\section{Conclusion}

Root length, dry weight and frond height significantly increased through the duration of experiment for $P$. calomelanos. These ferns can grow well without visual sign of phytotoxicity compared with the control. However, ferns grown in tailings mixture had lower root length by $25 \%$, lower dry matter yield by $48 \%$ and shorter frond height by $22 \%$. It is thus concluded that the ferns grown in tailings mixture underwent metal stress. Percent uptake of $\mathrm{As}$ and $\mathrm{Cu}$ by $P$. calomelanos was $(0.16)$ and $(0.013)$ respectively. Translocation factor of As of $P$. calomelanos was higher than one but translocation factor of $\mathrm{Cu}$ was lower than one. $P$. calomelanos can translocate As but most of the $\mathrm{Cu}$ was stored in belowground part.

According to heavy metal (As, $\mathrm{Cu}$ ) uptake data, $P$. calomelanos could uptake more $\mathrm{As}$ and $\mathrm{Cu}$ in plant boxes with plot height $9 \mathrm{~cm}$ and plant distance $15 \mathrm{~cm}$. This assumption though was only for 5 months experiment. Plants need to grow widely to absorb more heavy metal. Based on studies, the plant distance and plot height could be adjusted and set according to intended clean up time of heavy metals. Generally, it could be proposed that plot height $15 \mathrm{~cm}$ and plant distance $20 \mathrm{~cm}$ are suitable for the phytoremediation of As and $\mathrm{Cu}$ contaminated tailings mixture with the aid of P. calomelanos. 
The authors are greatly indebted to the organizers of $6^{\text {th }}$ Environmental Technology and Management Conference for their invitation, sponsorship and acceptance of our paper to make oral presentation in this conference. We also wish to appreciate AUN/SEED-Net program, JICA for their valuable support, sponsorship and encouragement to participate the conference and financial support for doing the research.

\section{References}

[1] F. M. H. Jadia C., "Phytoremediation of heavy metals : Recent techniques," African J. Biotechnol., vol. 8, no. 6, pp. 921-928, (2009)

[2] W. J. Rankin, Minerals, metals and sustainability: meeting future material needs. Collingwood: Vic.: CSIRO Pub, (2011)

[3] N. D. Briones, "Mining pollution: The case of the Baguio mining district, the philippines," Environ. Manage., vol. 11, no. 3, pp. 335-344, (1987)

[4] E. Rey and R. J. Saturay, "Small Scale Mining in the Philippines: Towards Genuine National Development," Baguio, (2005)

[5] L. J. L. Diaz, "Terminal Report- MinERS Project E: Nanofiber membrane adsorption for third level wastewater treatment method for smallscale mining operations," Quezon City, (2017)

[6] USDA, "Heavy Metal Soil Contamination," Soiil Qual. Urban Tech. Note, vol. 5, no. 3, pp. 1-7, (2000)

[7] Z. He, Shentu, X. Yang, Baligar, T. Zhang, and \& Stoffella, "Heavy Metal Contamination of Soils: Sources, Indicators, and Assessment," J. Environ. Indic., vol. 9, no. Table 2, pp. 17-18, (2015)

[8] P. Y. Yau and R. J. Murphy, "Biodegraded coco peat as a Horticultural Substrate," in In $X X V$ International Horticultural Congress, Part 7: Quality of Horticultural Products, pp. 275-78, (2000)

[9] H. Ali, E. Khan, and M. A. Sajad, "Phytoremediation of heavy metals-Concepts and applications," Chemosphere, vol. 91, no. 7, pp. 869-881, (2013)

[10] R. Nirola, M. Megharaj, T. Palanisami, R. Aryal, K. Venkateswarlu, and Ravi Naidu, "Evaluation of metal uptake factors of native trees colonizing an abandoned copper mine - a quest for phytostabilization," J. Sustain. Min., vol. 14, no. 3, pp. 115-123, (2015)

[11] A. O. Fayiga, L. Q. Ma, X. Cao, and B. Rathinasabapathi, "Effects of heavy metals on growth and arsenic accumulation in the arsenic hyperaccumulator Pteris vittata L.," Environ. Pollut., vol. 132, no. 2, pp. 289-296, (2004)

[12] L. M. Mateos, E. Ordóñez, M. Letek, and J. A. Gil, "Corynebacterium glutamicumas a model bacterium for the bioremediation of arsenic," Int. Microbiol., vol. 9, no. 3, pp. 207-215, (2006)

[13] A. M. Paz-Alberto and G. C. Sigua, "Phytoremediation: A Green Technology to
Remove Environmental Pollutants," Am. J. Clim. Chang., vol. 02, no. 01, pp. 71-86, (2013)

[14] H. Bothe, "Detoxification of Heavy Metals," vol. 30, pp. 35-58, (2011)

[15] A. P. G. C. Marques, A. O. S. S. Rangel, and P. M. L. Castro, Remediation of Heavy Metal Contaminated Soils: Phytoremediation as a Potentially Promising Clean-Up Technology, vol. 39, no. 8. (2009)

[16] N. D. Mganga, "The Potential of Bioaccumulation and Translocation of Heavy Metals in Plant Species Growing around the Tailing Dam in Tanzania," vol. 3, no. 10, pp. 690-697, (2014)

[17] B. Lorestani, M. Cheraghi, and N. Yousefi, "Phytoremediation Potential of Native Plants Growing on a Heavy Metals Contaminated Soil of Copper mine in Iran," World Acad. Sci. Eng. Technol., vol. 53, no. 5, pp. 377-382, (2011)

[18] P. Visoottiviseth, K. Francesconi, and W. Sridokchan, "The potential of Thai indigenous plant species for the phytoremediation of arsenic contaminated land," Environ. Pollut., vol. 118, no. 3, pp. 453-461, (2002)

[19] L. Q. Ma, K. M. Komar, C. Tu, W. Zhang, and Y. Cai, "A fern that hyperaccumulates arsenic.," Nature, vol. 409, p. 579, (2001)

[20] T. Chen, C. Wei, Z. Huang, Q. Huang, Q. Lu, and Z. Fan, "Arsenic hyperaccumulator Pteris vittata L. and its arsenic accumulation.," Chinese Sci. Bull., vol. 47, pp. 902-905, (2002)

[21] K. Francesconi, P. Visoottiviseth, W. Sridokchan, and W. Goessler, "Arsenic species in an arsenic hyperaccumulating fern, Pityrogramma calomelanos: A potential phytoremediator of arsenic-contaminated soils," Sci. Total Environ., vol. 284, no. 1-3, pp. 27-35, (2002)

[22] T. K. A. Bui, D. K. Dang, T. K. Nguyen, N. M. Nguyen, Q. T. Nguyen, and H. C. Nguyen, "Phytoremediation of heavy metal polluted soil and water in Vietnam," J. Viet. Env., vol. 6, no. 1, pp. 47-51, (2014)

[23] F. Perlatti, T. O. Ferreira, R. E. Romero, M. C. G. Costa, and X. L. Otero, "Copper accumulation and changes in soil physicalchemical properties promoted by native plants in an abandoned mine site in northeastern Brazil: Implications for restoration of mine sites," Ecol. Eng., vol. 82, pp. 103-111, (2015)

[24] J. K. A. Dahilan and J. Q. Dalagan, "Bioavailability and Accumulation Assessment of Copper in Pityrogramma calomelanos," Philipp. J. Sci., vol. 146, pp. 331-338, (2017)

[25] C. Koller, J. Patrick, R. Rose, C. Offler, and G. MacFarlane, "Arsenic and heavy metal accumulation by Pteris vittata L. and P. umbrosa R. Br," Bull. Environ. Contam. adn Toxicol., vol. 80, no. 2, p. 128, (2008)

[26] G. Yang and H. He, "A review of Pteridophyta Potential in Phytoremediation of Heavy Metal Contaminated Environments," Asian Agric. Res., 
vol. 8, no. 11, pp. 49-53,60, (2016)

[27] J. L. C. Algo, T. R. Perez, R. E. C. Perez, and R. J. R. Claveria, "A Survey of Indigenous Copper Metallophytes in the Mankayan Mineral District, Benguet, Philippines, with Potential Applications to Post-Mining Rehabilitation," In Abstracts of Papers, 36th NAST Annual Scientific Meeting, Transactums of the National Academy of Science and Technology (ISSN 0115-88-48) Vol 36, No.1, (2014)

[28] Y. P. Kalra, Handbook of Reference Methods for Plant Analysis. New York: CRC Press Taylor \& Francis Group, (1998)

[29] S. Khalid, M. Shahid, N. K. Niazi, B. Murtaza, I. Bibi, and C. Dumat, "A comparison of technologies for remediation of heavy metal contaminated soils," J. Geochemical Explor., vol. 182, pp. 247-268, (2017)

[30] D. Egamberdieva, D. Jabborova, and A. Hashem, "Pseudomonas induces salinity tolerance in cotton (Gossypium hirsutum) and resistance to Fusarium root rot through the modulation of indole-3-acetic acid.," Saudi J. Biol., (2015)

[31] WHO, "World Health Organization (WHO).," Avenue Appia 201211 Geneva 27 Switzerland, (2008)

[32] R. A. Efroymson, M. E. Will, G. W. Suter, and A. C. Wooten, "Toxicological Benchmarks for Screening Contaminants of Potential Concern for Effects on Terrestrial Plants: 1997 Revision," (1997)

[33] M. Rezvani and F. Zaefarian, "Bioaccumulation and translocation factors of cadmium and lead in Aeluropus littoralis," Aust. J. Agric. Eng., vol. 2, no. 4, pp. 114-119, (2011)

[34] A. Baker and R. Brooks, "Terrestrial higher plants which hyperaccumulate metallic elements. A review of their distribution ecology and phytochemistry.," Biorecovery, vol. 1, pp. 81126, (1989)

[35] A. Kumari, B. Lal, Y. B. Pakade, and P. Chand, "Assessment of bioaccumulation of heavy metal by Pteris vittata 1 . growing in the vicinity of fly ash," Int. J. Phytoremediation, vol. 13, no. 8, pp. 779-787, (2011)

[36] A. Kumari, B. Lal, Y. B. Pakade, and P. Chand, "Assessment of Bioaccumulation of Heavy Metal by Pteris Vittata L. Growing in the Vicinity of Fly Ash," Int. J. Phytoremediation, vol. 13, pp. 779-787, (2011)

[37] A. O. Fayiga, L. Q. Ma, and B. Rathinasabapathi, "Effects of nutrients on arsenic accumulation by arsenic hyperaccumulator Pteris vittata L.," Environ. Exp. Bot., vol. 62, no. 3, pp. 231-237, (2008)

[38] M. I. Silva Gonzaga, J. A. Gonzaga Santos, and L. Q. Ma, "Arsenic phytoextraction and hyperaccumulation by fern species," Sci. Agric., vol. 63, pp. 90-101, (2006)

[39] N. K. Niazi, B. Singh, L. Van Zwieten, and A. G. Kachenko, "Phytoremediation of an arsenic- contaminated site using Pteris vittata L. and Pityrogrammacalomelanos var. austroamericana: A long-term study," Environ. Sci. Pollut. Res., vol. 19, no. 8, pp. 3506-3515, (2012)

[40] S. Mathews, "Arsenic Hyperaccumulation by Pteris vittata L.- Arsenic Transformation, Uptake and Environmental Impact," The University of Florida, (2011)

[41] K. J. Verdell, "Microbial Volatilization: Bioremediation of Soils Contaminated with Arsenic," The Ohio State University, (2008)

[42] X. Y. Liao, T. B. Chen, M. Lei, Z. C. Huang, X. Y. Xiao, and Z. Z. An, "Root distributions and elemental accumulations of Chinese brake (Pteris vittata L.) from As-contaminated soils," Plant Soil, vol. 261, no. 1-2, pp. 109-116, (2004)

[43] D. Egamberdieva, E. F. Abd-Allah, and J. A. T. da Silva, "Microbially Assisted Phytoremediation of Heavy Metal-Contaminated Soils," Plant Metal Interaction: Emerging Remediation Techniques, pp. 483-498, (2016)

[44] I. Yruela, "Toxic metals in plants," Brazilian J. Plant Physiol., vol. 17, no. 1, pp. 145-156, (2005) 